\title{
Licorice Extracts Inhibits growth of Non-Small Cell Lung Cancer by Down-Regulating CDK4-Cyclin D1 Complex and Increasing CD8+ T Cell Infiltration
}

\section{Ruifei Huang}

North-West University https://orcid.org/0000-0001-8035-0307

Jinglin Zhu

North-West University

Ruijie Yang

North-West University

Yue Xiao

North-West University

Jiangna Yan

North-West University

Chunli Zheng

Northwest University

Wei Xiao

Jiangsu Kanion Pharmaceutical Co Ltd

Chao Huang ( $\nabla$ huangchao1989@nwafu.edu.cn )

Northwest University https://orcid.org/0000-0003-1186-0973

Yonghua Wang

North-West University

Primary research

Keywords: tumor microenvironment, NSCLC, licorice, systems pharmacology strategy

Posted Date: May 6th, 2021

DOl: https://doi.org/10.21203/rs.3.rs-488288/v1

License: (c) (i) This work is licensed under a Creative Commons Attribution 4.0 International License.

Read Full License 


\section{Abstract}

Background: Targeting tumor microenvironment (TME) may provide therapeutic activity and selectivity in treating cancers. Therefore, an improved understanding of the mechanism by which drug targeting TME would enable more informed and effective treatment measures. Glycyrrhiza uralensis Fisch (GUF, licorice), a widely used herb medicine, which has shown promising immunomodulatory activity and antitumor activity. However, the molecular mechanism of this biological activity has not been fully elaborated.

Methods: Here, potential active compounds and specific targets of licorice that trigger the antitumor immunity were predicted with a systems pharmacology strategy. Flow cytometry technique was used to detect cell cycle profile and $\mathrm{CD} 8^{+} \mathrm{T}$ cell infiltration of licorice treatment. And anti-tumor activity of licorice was evaluated in C57BL/6 mice.

Results: We reported the G0/G1 growth phase cycle arrest of tumor cells induced by licorice that is related with the down-regulation of CDK4-Cyclin D1 complex, which subsequently led to increased protein abundance of PD-L1. Further, in vivo studies demonstrated that mitigation the outgrowth of NSCLC tumor induced by licorice was reliant on increased antigen presentation and improved $\mathrm{CD} 8^{+} \mathrm{T}$ cell infiltration.

Conclusions: Briefly, our findings improved understanding of the anti-tumor effects of licorice with the systems pharmacology strategy, thereby promoting the development of natural products in the prevention or treatment of cancers.

Trial registration: Not applicable

\section{Introduction}

Lung cancer is the most prevalent diagnosed cancer worldwide and a major contributor of cancer mortality. And non-small cell lung cancer (NSCLC) accounts for approximately $85 \%$ of the diagnosed lung cancers $[1-3]$. In the recent years, immunotherapy targeting $T$ cells has increasingly shown its potentiality in treatment of a wide variety of solid tumors, such as non-small cell lung cancer (NSCLC) [4-6]. Although encouraging, it is the fact that still only a small number of patients obtain long-term benefit, which is likely correlated with the complex network of the tumor microenvironment (TME)[7]. The tumor microenvironment (TME), a complex physical and biochemical system, playing a pivotal role in tumor initiation, progression, metastasis, and drug resistance[8]. It contains cells of the immune system, tumor cells, tumor vasculature and extracellular matrices (ECM) [9]. Among them, tumor cells could express inhibitory ligands that suppress the T-cell activity to evade immune destruction. Immune cells could produce some cytokines, growth factors, enzymes, and angiogenic mediators to promote growth of tumor[10]. And ECM consists of biological barriers around the tumor tissue to hamper lymphocyte penetration. Therefore, better understanding of the interactions in the TME that would increase the ratio of patients benefiting from these therapies are essential. 
Traditional herb medicines and herbal derived components are playing increasingly critical roles in prevention and treatment of cancers[11, 12]. Compared with conventional chemotherapy, they are of low toxicity and pleiotropic actions, targeting the complex network of TME by modulating multiple cellsignaling pathways involved in immune. Thereby, natural products could be a great repository for development of novel therapeutic approaches in cancer treatment. As a well-known herbal medicine used worldwide for centuries, to date, several reports have been published complicating the immunomodulatory activity of licorice on multiple cancers, including colon cancer, breast cancer, acute myeloid leukemia, gastric cancer, melanoma, and prostate cancer[13-16]. However, the molecular underpinnings of this biological activity that licorice exert its immunomodulatory potential have not been fully elaborated.

To address this question, we used a systems pharmacology strategy to elaborate that how licorice exert anti-tumor effects by regulating multiple immune-related signaling pathways and targets, influencing cell cycle progression, and mitigate the growth of NSCLC cancer. First, by screening the poly-pharmacology molecules of licorice, predicting the targets of active compounds, constructing the networks, and linking the targets to the immune phenotype in lung cancer patients, we observed that active ingredients of licorice targeted a great variety of tumor-related signaling pathways, including cell cycle, inflammation, and migration. Then, we used in vitro and in vivo experiments to reveal anti-tumor effects of licorice. On the one hand, we found that licorice down-regulates CDK4-Cyclin D1 complex, resulting in G0/G1 phase arrest and increased PD-L1 levels in lung cancer cells. On the other hand, we also found that licorice increased antigen presentation and infiltration of $\mathrm{CD} 8^{+} \mathrm{T}$ cell, significantly decreased tumor volume of mouse models of NSCLC in vivo. Taken together, our studies indicate that systems pharmacology strategy greatly uncovered the action mechanism of poly-pharmacology molecules of licorice, contributing the use of natural products for further anti-cancer drug development.

\section{Results}

\section{1 , Systems pharmacology uncovers that licorice targets cell cycle progression and immune process}

As a comprehensive system, the systems pharmacology approach was used to investigate the complex molecular mechanisms of licorice as a treatment for NSCLC in this study (as shown in Fig. 1).

Altogether, 89 ingredients were identified in licorice with the searching literatures and using Traditional Chinese Medicine Systems Pharmacology Database (TCMSP), and a total of 23 active ingredients (shown in Table 1) were screened out by in silico ADME (absorption, distribution, metabolism, and excretion) system, with the criteria of oral bioavailability $(O B) \geq 50 \%$ and drug-likeness $(D L) \geq 0.40$. Then, predicted by the weighted ensemble similarity method (WES) [17] and systematic drug targeting tool (SysDT)[18], we found that these 23 ingredients in licorice were investigated interacted with 109 targets (shown in Table 2 and table S1). And we constructed the compound-target (C-T) network graph to greatly illustrate the relationships between compounds and targets. In terms of the targets interacted with 
licorice, we observed that most of which were related to cell cycle, immune, inflammation, cancer and neoplasm metastasis with higher scores. Specifically, including CDK2, ESR1, PPARG, ESRRA, PRKACA, CXCL8, PLAA, RXRB, MAPK14 and so on (shown in Fig. 2a).

To detect the potential role of these targets, we performed Gene Ontology (GO) biological processes enrichment analysis, and found that most of biological processes were involved in immune progress. Including "regulation of myeloid cell differentiation", "neutrophil mediated immunity", and "regulation of cytokine production involved in inflammatory response" (shown in Fig. $2 \mathrm{~b}$ and $2 \mathrm{c}$ ). Then, to further understand the relationship between licorice and diseases, using the Database for Annotation Visualization, and Integrated Discovery (DAVID), we performed the Kyoto Encyclopedia of Genes and Genomes (KEGG) pathway enrichment analysis. And the results showed that the most targets of licorice mainly enriched in signaling pathways related to the cancer process. Including "non-small cell lung cancer", "small cell lung cancer" "pathways in cancer", "prostate cancer", "T cell receptor signaling pathway" and so on (Fig. 2d).

Therefore, the systems pharmacology analysis uncovers that licorice mainly targets cell cycle and immune progress to exert its anti-cancer effect, and paves the way for in-depth understanding of the multi-target molecular mechanism of licorice treating for NSCLC.

Table 1. Chemical information and pharmacokinetics parameters of 23 active compounds of licorice. 


\begin{tabular}{|c|c|c|c|c|c|c|c|}
\hline MOL_ID & Counpounds & Structure & Categories & $\mathrm{OB}$ & DL & HL & Degree \\
\hline MOL.DOS008 & $\begin{array}{l}\text { Glycyrrhiza flavoool } \\
\text { A }\end{array}$ & & Flavonoids & 41.28 & 0.60 & 13.71 & 30 \\
\hline MOL.001484 & Inermine & & Flavonoids & 75.18 & 0.54 & 11.72 & 35 \\
\hline MOLDO0211 & Mairin & & Sapoains & 55.38 & 0.78 & 8.87 & 16 \\
\hline MOL.002311 & Glycyrol & & coumestans & 90.78 & 0.67 & 9.85 & 14 \\
\hline MOL.D04808 & glyasperia B & & Others & 65.22 & 0.44 & 16.1 & 31 \\
\hline MOL.004810 & slyasperiv F & & Others & 75.84 & 0.54 & 15.64 & 33 \\
\hline MOL.004820 & banzonols W & & Flavonoids & 50.48 & 0.52 & 0.15 & 38 \\
\hline MoL.004855 & Licoricone & & Flavonoids & 63.58 & 0.47 & 16.37 & 23 \\
\hline MOL.004863 & $\begin{array}{l}\text { 3-(3,4- } \\
\text { dihydroxypheayl)- } \\
\text { 5,7-dihydroxy-8-(3- } \\
\text { methylbut-2- } \\
\text { enyl)chromon }\end{array}$ & & Ochers & 66.37 & 0.41 & 15.81 & 26 \\
\hline MoL.004879 & Glycyrin & & Coumarins & 52.61 & 0.47 & 1.31 & 22 \\
\hline MOL.004885 & licoisoflavanooc & & Flavonoids & 52.47 & 0.54 & 15.67 & 31 \\
\hline MOL.004891 & shinpterocapàn & & Flavonoids & 80.3 & 0.73 & 6.5 & 44 \\
\hline
\end{tabular}




\begin{tabular}{|c|c|c|c|c|c|c|c|}
\hline MOL.004903 & liquiritin & & Flavonoids & 65.69 & 0.74 & 17.96 & 21 \\
\hline MOL.D04904 & licopyranocoumaria & & Flavonoids & 80.36 & 0.65 & 0.08 & 25 \\
\hline MOLDO4908 & Glabridin & & Flavonoids & 53.25 & 0.47 & 0.03 & 39 \\
\hline MOL.004912 & Glabrone & & Flavonoids & 52.51 & 0.5 & 16.09 & 38 \\
\hline MOL.D04914 & $\begin{array}{l}\text { 1,3-dibydroxy-8,9- } \\
\text { dimethoxy-6- } \\
\text { benzofunano[3,2- } \\
\text { c]chromenone }\end{array}$ & & Others & 62.9 & 0.53 & 9.32 & 20 \\
\hline MOL.004959 & Methoxyphaseodlidin & & Flavonoids & 69.98 & 0.64 & 9.53 & 35 \\
\hline MOL.005001 & Gancaonìn H & & Ochers & 50.1 & 0.78 & 16.64 & 30 \\
\hline MOLDOS003 & Licoagrocapin & & Flavonoids & 58.81 & 0.58 & 9.45 & 37 \\
\hline MOL.Dos007 & Glyasperias M & & Flavonoids & 72.67 & 0.59 & 15.57 & 39 \\
\hline MOLDOS012 & Licoagroisoflavone & & Flavonoids & 57.28 & 0.49 & 19.64 & 36 \\
\hline MOL.005017 & Phaseed & & coumestans & 78.77 & 0.58 & 9.64 & 21 \\
\hline
\end{tabular}

$\mathrm{OB}$, onal bioavailability; DL, drug-likeness; HL, Half-life 
Table 2

The targets information of licorice.

\begin{tabular}{|c|c|c|c|c|}
\hline $\begin{array}{l}\text { UniProt- } \\
\text { ID }\end{array}$ & Protein names & $\begin{array}{l}\text { Gene } \\
\text { names }\end{array}$ & Degree & Species \\
\hline P0DP23 & Calmodulin-1 & CALM1 & 19 & $\begin{array}{l}\text { homo } \\
\text { sapiens }\end{array}$ \\
\hline P35368 & Alpha-1B adrenergic receptor & ADRA1B & 5 & $\begin{array}{l}\text { homo } \\
\text { sapiens }\end{array}$ \\
\hline P00918 & Carbonic anhydrase 2 & CA2 & 17 & $\begin{array}{l}\text { homo } \\
\text { sapiens }\end{array}$ \\
\hline P18031 & Tyrosine-protein phosphatase non-receptor type 1 & PTPN1 & 17 & $\begin{array}{l}\text { homo } \\
\text { sapiens }\end{array}$ \\
\hline P46098 & 5-hydroxytryptamine receptor $3 \mathrm{~A}$ & HTR3A & 1 & $\begin{array}{l}\text { homo } \\
\text { sapiens }\end{array}$ \\
\hline P20309 & Muscarinic acetylcholine receptor M3 & CHRM3 & 3 & $\begin{array}{l}\text { homo } \\
\text { sapiens }\end{array}$ \\
\hline P23219 & Prostaglandin G/H synthase 1 & PTGS1 & 8 & $\begin{array}{l}\text { homo } \\
\text { sapiens }\end{array}$ \\
\hline Q14524 & Sodium channel protein type 5 subunit alpha & SCN5A & 11 & $\begin{array}{l}\text { homo } \\
\text { sapiens }\end{array}$ \\
\hline P07477 & Trypsin-1 & PRSS1 & 18 & $\begin{array}{l}\text { homo } \\
\text { sapiens }\end{array}$ \\
\hline P17612 & $\begin{array}{l}\text { cAMP-dependent protein kinase catalytic subunit } \\
\text { alpha }\end{array}$ & PRKACA & 6 & $\begin{array}{l}\text { homo } \\
\text { sapiens }\end{array}$ \\
\hline 014757 & Serine/threonine-protein kinase & CHEK1 & 18 & $\begin{array}{l}\text { homo } \\
\text { sapiens }\end{array}$ \\
\hline P11309 & Serine/threonine-protein kinase pim-1 & PIM1 & 20 & $\begin{array}{l}\text { homo } \\
\text { sapiens }\end{array}$ \\
\hline P35354 & Prostaglandin G/H synthase 2 & PTGS2 & 20 & $\begin{array}{l}\text { homo } \\
\text { sapiens }\end{array}$ \\
\hline P27487 & Dipeptidyl peptidase 4 & DPP4 & 13 & $\begin{array}{l}\text { homo } \\
\text { sapiens }\end{array}$ \\
\hline Q16539 & Mitogen-activated protein kinase 14 & MAPK14 & 13 & $\begin{array}{l}\text { homo } \\
\text { sapiens }\end{array}$ \\
\hline P48736 & $\begin{array}{l}\text { Phosphatidylinositol 4,5-bisphosphate 3-kinase } \\
\text { catalytic subunit gamma isoform }\end{array}$ & PIK3CG & 3 & $\begin{array}{l}\text { homo } \\
\text { sapiens }\end{array}$ \\
\hline P21730 & C5a anaphylatoxin chemotactic receptor 1 & AR & 22 & $\begin{array}{l}\text { homo } \\
\text { sapiens }\end{array}$ \\
\hline
\end{tabular}




\begin{tabular}{|c|c|c|c|c|}
\hline $\begin{array}{l}\text { UniProt- } \\
\text { ID }\end{array}$ & Protein names & $\begin{array}{l}\text { Gene } \\
\text { names }\end{array}$ & Degree & Species \\
\hline P49841 & Glycogen synthase kinase-3 beta & GSK3B & 17 & $\begin{array}{l}\text { homo } \\
\text { sapiens }\end{array}$ \\
\hline P24941 & Cyclin-dependent kinase 2 & CDK2 & 17 & $\begin{array}{l}\text { homo } \\
\text { sapiens }\end{array}$ \\
\hline Q92731 & Estrogen receptor beta & ESR2 & 16 & $\begin{array}{l}\text { homo } \\
\text { sapiens }\end{array}$ \\
\hline P07900 & Heat shock protein HSP 90-alpha & HSP90AA1 & 12 & $\begin{array}{l}\text { homo } \\
\text { sapiens }\end{array}$ \\
\hline P20248 & Cyclin-A2 & CCNA2 & 20 & $\begin{array}{l}\text { homo } \\
\text { sapiens }\end{array}$ \\
\hline $\mathrm{B} 2 \mathrm{RXH} 2$ & Lysine-specific demethylase 4E & KDM4E & 1 & $\begin{array}{l}\text { homo } \\
\text { sapiens }\end{array}$ \\
\hline 000767 & Stearoyl-CoA desaturase & SCD & 10 & $\begin{array}{l}\text { homo } \\
\text { sapiens }\end{array}$ \\
\hline 095622 & Adenylate cyclase type 5 & ADCY5 & 7 & $\begin{array}{l}\text { homo } \\
\text { sapiens }\end{array}$ \\
\hline P08842 & Steryl-sulfatase & STS & 13 & $\begin{array}{l}\text { homo } \\
\text { sapiens }\end{array}$ \\
\hline P11474 & Steroid hormone receptor ERR1 & ESRRA & 12 & $\begin{array}{l}\text { homo } \\
\text { sapiens }\end{array}$ \\
\hline P12644 & Bone morphogenetic protein 4 & BMP4 & 1 & $\begin{array}{l}\text { homo } \\
\text { sapiens }\end{array}$ \\
\hline P16152 & Carbonyl reductase [NADPH] 1 & CBR1 & 7 & $\begin{array}{l}\text { homo } \\
\text { sapiens }\end{array}$ \\
\hline P28223 & 5-hydroxytryptamine receptor $2 \mathrm{~A}$ & HTR2A & 18 & $\begin{array}{l}\text { homo } \\
\text { sapiens }\end{array}$ \\
\hline P51843 & Nuclear receptor subfamily 0 group B member 1 & NROB1 & 7 & $\begin{array}{l}\text { homo } \\
\text { sapiens }\end{array}$ \\
\hline Q99814 & Endothelial PAS domain-containing protein 1 & EPAS1 & 3 & $\begin{array}{l}\text { homo } \\
\text { sapiens }\end{array}$ \\
\hline Q9Y263 & Phospholipase A-2-activating protein & PLAA & 3 & $\begin{array}{l}\text { homo } \\
\text { sapiens }\end{array}$ \\
\hline 060218 & Aldo-keto reductase family 1 member B10 & AKR1B10 & 1 & $\begin{array}{l}\text { homo } \\
\text { sapiens }\end{array}$ \\
\hline P05093 & Steroid 17-alpha-hydroxylase/17,20 lyase & CYP17A1 & 1 & $\begin{array}{l}\text { homo } \\
\text { sapiens }\end{array}$ \\
\hline
\end{tabular}




\begin{tabular}{|c|c|c|c|c|}
\hline $\begin{array}{l}\text { UniProt- } \\
\text { ID }\end{array}$ & Protein names & $\begin{array}{l}\text { Gene } \\
\text { names }\end{array}$ & Degree & Species \\
\hline P10276 & Retinoic acid receptor alpha & RARA & 1 & $\begin{array}{l}\text { homo } \\
\text { sapiens }\end{array}$ \\
\hline P11413 & Glucose-6-phosphate 1-dehydrogenase & G6PD & 1 & $\begin{array}{l}\text { homo } \\
\text { sapiens }\end{array}$ \\
\hline P11473 & Vitamin D3 receptor & VDR & 1 & $\begin{array}{l}\text { homo } \\
\text { sapiens }\end{array}$ \\
\hline P16662 & UDP-glucuronosyltransferase 2B7 & UGT2B7 & 1 & $\begin{array}{l}\text { homo } \\
\text { sapiens }\end{array}$ \\
\hline P18405 & 3-oxo-5-alpha-steroid 4-dehydrogenase 1 & SRD5A1 & 1 & $\begin{array}{l}\text { homo } \\
\text { sapiens }\end{array}$ \\
\hline P19793 & Retinoic acid receptor RXR-alpha & RXRA & 7 & $\begin{array}{l}\text { homo } \\
\text { sapiens }\end{array}$ \\
\hline P36873 & $\begin{array}{l}\text { Serine/threonine-protein phosphatase PP1-gamma } \\
\text { catalytic subunit }\end{array}$ & PPP1CC & 1 & $\begin{array}{l}\text { homo } \\
\text { sapiens }\end{array}$ \\
\hline P80365 & Corticosteroid 11-beta-dehydrogenase isozyme 2 & HSD11B2 & 2 & $\begin{array}{l}\text { homo } \\
\text { sapiens }\end{array}$ \\
\hline Q08828 & Adenylate cyclase type 1 & ADCY1 & 1 & $\begin{array}{l}\text { homo } \\
\text { sapiens }\end{array}$ \\
\hline Q12908 & Ileal sodium/bile acid cotransporter & SLC10A2 & 1 & $\begin{array}{l}\text { homo } \\
\text { sapiens }\end{array}$ \\
\hline Q9NRD8 & Dual oxidase 2 & DUOX2 & 1 & $\begin{array}{l}\text { homo } \\
\text { sapiens }\end{array}$ \\
\hline Q9UBM7 & 7-dehydrocholesterol reductase & DHCR7 & 1 & $\begin{array}{l}\text { homo } \\
\text { sapiens }\end{array}$ \\
\hline P03372 & Estrogen receptor & ESR1 & 13 & $\begin{array}{l}\text { homo } \\
\text { sapiens }\end{array}$ \\
\hline P03420 & Fusion glycoprotein F2 & $\mathrm{F} 2$ & 18 & $\begin{array}{l}\text { homo } \\
\text { sapiens }\end{array}$ \\
\hline P37231 & Peroxisome proliferator-activated receptor gamma & PPARG & 19 & $\begin{array}{l}\text { homo } \\
\text { sapiens }\end{array}$ \\
\hline P30291 & Wee1-like protein kinase & WEE1 & 3 & $\begin{array}{l}\text { homo } \\
\text { sapiens }\end{array}$ \\
\hline P23141 & Liver carboxylesterase 1 & CES2 & 7 & $\begin{array}{l}\text { homo } \\
\text { sapiens }\end{array}$ \\
\hline P05067 & Amyloid-beta precursor protein & APP & 7 & $\begin{array}{l}\text { homo } \\
\text { sapiens }\end{array}$ \\
\hline
\end{tabular}




\begin{tabular}{|c|c|c|c|c|}
\hline $\begin{array}{l}\text { UniProt- } \\
\text { ID }\end{array}$ & Protein names & $\begin{array}{l}\text { Gene } \\
\text { names }\end{array}$ & Degree & Species \\
\hline P09960 & Leukotriene A-4 hydrolase & LTA4H & 10 & $\begin{array}{l}\text { homo } \\
\text { sapiens }\end{array}$ \\
\hline P10636 & Microtubule-associated protein tau & MAPT & 9 & $\begin{array}{l}\text { homo } \\
\text { sapiens }\end{array}$ \\
\hline Q04206 & Transcription factor p65 & RELA & 6 & $\begin{array}{l}\text { homo } \\
\text { sapiens }\end{array}$ \\
\hline P22303 & Acetylcholinesterase & ACHE & 11 & $\begin{array}{l}\text { homo } \\
\text { sapiens }\end{array}$ \\
\hline Q15596 & Nuclear receptor coactivator 2 & $\mathrm{NCOA} 2$ & 10 & $\begin{array}{l}\text { homo } \\
\text { sapiens }\end{array}$ \\
\hline P11388 & DNA topoisomerase 2-alpha & TOP2A & 11 & $\begin{array}{l}\text { homo } \\
\text { sapiens }\end{array}$ \\
\hline P35968 & Vascular endothelial growth factor receptor 2 & KDR & 8 & $\begin{array}{l}\text { homo } \\
\text { sapiens }\end{array}$ \\
\hline P00742 & Coagulation factor $X$ & F10 & 16 & $\begin{array}{l}\text { homo } \\
\text { sapiens }\end{array}$ \\
\hline P08709 & Coagulation factor VII, EC 3.4.21.21 & F7 & 7 & $\begin{array}{l}\text { homo } \\
\text { sapiens }\end{array}$ \\
\hline P11926 & Ornithine decarboxylase & ODC1 & 10 & $\begin{array}{l}\text { homo } \\
\text { sapiens }\end{array}$ \\
\hline P14061 & 17-beta-hydroxysteroid dehydrogenase type 1 & HSD17B1 & 5 & $\begin{array}{l}\text { homo } \\
\text { sapiens }\end{array}$ \\
\hline P18054 & olyunsaturated fatty acid lipoxygenase ALOX12 & ALOX12 & 7 & $\begin{array}{l}\text { homo } \\
\text { sapiens }\end{array}$ \\
\hline Q9UHC3 & Acid-sensing ion channel 3 & ASIC3 & 12 & $\begin{array}{l}\text { homo } \\
\text { sapiens }\end{array}$ \\
\hline P05091 & Aldehyde dehydrogenase & ALDH2 & 4 & $\begin{array}{l}\text { homo } \\
\text { sapiens }\end{array}$ \\
\hline P37058 & Testosterone 17-beta-dehydrogenase 3 & HSD17B3 & 3 & $\begin{array}{l}\text { homo } \\
\text { sapiens }\end{array}$ \\
\hline Q13887 & Krueppel-like factor 5 & KLF5 & 2 & $\begin{array}{l}\text { homo } \\
\text { sapiens }\end{array}$ \\
\hline Q15788 & Nuclear receptor coactivator 1 & NCOA1 & 6 & $\begin{array}{l}\text { homo } \\
\text { sapiens }\end{array}$ \\
\hline Q12809 & $\begin{array}{l}\text { Potassium voltage-gated channel subfamily } \mathrm{H} \\
\text { member } 2\end{array}$ & $\mathrm{KCNH} 2$ & 5 & $\begin{array}{l}\text { homo } \\
\text { sapiens }\end{array}$ \\
\hline
\end{tabular}




\begin{tabular}{|c|c|c|c|c|}
\hline $\begin{array}{l}\text { UniProt- } \\
\text { ID }\end{array}$ & Protein names & $\begin{array}{l}\text { Gene } \\
\text { names }\end{array}$ & Degree & Species \\
\hline Q9H4B7 & Tubulin beta- 1 chain & TUBB1 & 5 & $\begin{array}{l}\text { homo } \\
\text { sapiens }\end{array}$ \\
\hline P12268 & Inosine-5'-monophosphate dehydrogenase 2 & IMPDH2 & 1 & $\begin{array}{l}\text { homo } \\
\text { sapiens }\end{array}$ \\
\hline P11308 & Transcriptional regulator ERG & ERG & 1 & $\begin{array}{l}\text { homo } \\
\text { sapiens }\end{array}$ \\
\hline P45985 & $\begin{array}{l}\text { Dual specificity mitogen-activated protein kinase } \\
\text { kinase } 4\end{array}$ & MAP2K4 & 1 & $\begin{array}{l}\text { homo } \\
\text { sapiens }\end{array}$ \\
\hline P25100 & Alpha-1D adrenergic receptor & ADRA1D & 2 & $\begin{array}{l}\text { homo } \\
\text { sapiens }\end{array}$ \\
\hline P36544 & Neuronal acetylcholine receptor subunit alpha-7 & CHRNA7 & 1 & $\begin{array}{l}\text { homo } \\
\text { sapiens }\end{array}$ \\
\hline P28702 & Retinoic acid receptor RXR-beta & RXRB & 2 & $\begin{array}{l}\text { homo } \\
\text { sapiens }\end{array}$ \\
\hline P08912 & Muscarinic acetylcholine receptor M5 & CHRM5 & 1 & $\begin{array}{l}\text { homo } \\
\text { sapiens }\end{array}$ \\
\hline P11229 & Muscarinic acetylcholine receptor M1 & CHRM1 & 2 & $\begin{array}{l}\text { homo } \\
\text { sapiens }\end{array}$ \\
\hline P07550 & Beta-2 adrenergic receptor & ADRB2 & 4 & $\begin{array}{l}\text { homo } \\
\text { sapiens }\end{array}$ \\
\hline P35372 & Mu-type opioid receptor & OPRM1 & 1 & $\begin{array}{l}\text { homo } \\
\text { sapiens }\end{array}$ \\
\hline P41143 & Delta-type opioid receptor & OPRD1 & 1 & $\begin{array}{l}\text { homo } \\
\text { sapiens }\end{array}$ \\
\hline 060502 & Protein O-GlcNAcase & OGA & 1 & $\begin{array}{l}\text { homo } \\
\text { sapiens }\end{array}$ \\
\hline P08514 & Integrin alpha-Ilb & ITGA2B & 1 & $\begin{array}{l}\text { homo } \\
\text { sapiens }\end{array}$ \\
\hline P16278 & Beta-galactosidase & GLB1 & 1 & $\begin{array}{l}\text { homo } \\
\text { sapiens }\end{array}$ \\
\hline P28838 & Cytosol aminopeptidase & LAP3 & 1 & $\begin{array}{l}\text { homo } \\
\text { sapiens }\end{array}$ \\
\hline P31639 & Sodium/glucose cotransporter 2 & SLC5A2 & 1 & $\begin{array}{l}\text { homo } \\
\text { sapiens }\end{array}$ \\
\hline P53396 & ATP-citrate synthase & ACLY & 1 & $\begin{array}{l}\text { homo } \\
\text { sapiens }\end{array}$ \\
\hline
\end{tabular}




\begin{tabular}{|c|c|c|c|c|}
\hline $\begin{array}{l}\text { UniProt- } \\
\text { ID }\end{array}$ & Protein names & $\begin{array}{l}\text { Gene } \\
\text { names }\end{array}$ & Degree & Species \\
\hline P54577 & Tyrosine-tRNA ligase, cytoplasmic & YARS & 1 & $\begin{array}{l}\text { homo } \\
\text { sapiens }\end{array}$ \\
\hline 075907 & Diacylglycerol 0-acyltransferase 1 & DGAT1 & 3 & $\begin{array}{l}\text { homo } \\
\text { sapiens }\end{array}$ \\
\hline P14222 & Perforin-1 & PRF1 & 1 & $\begin{array}{l}\text { homo } \\
\text { sapiens }\end{array}$ \\
\hline P51684 & C-C chemokine receptor type 6 & CCR6 & 2 & $\begin{array}{l}\text { homo } \\
\text { sapiens }\end{array}$ \\
\hline P05177 & Cytochrome P450 1A2 & CYP1A2 & 1 & $\begin{array}{l}\text { homo } \\
\text { sapiens }\end{array}$ \\
\hline Q16678 & Cytochrome P450 1B1 & CYP1B1 & 1 & $\begin{array}{l}\text { homo } \\
\text { sapiens }\end{array}$ \\
\hline Q92959 & $\begin{array}{l}\text { Solute carrier organic anion transporter family } \\
\text { member } 2 A 1\end{array}$ & SLCO2A1 & 1 & $\begin{array}{l}\text { homo } \\
\text { sapiens }\end{array}$ \\
\hline P29474 & Nitric oxide synthase & Nos3 & 2 & $\begin{array}{l}\text { homo } \\
\text { sapiens }\end{array}$ \\
\hline P08684 & Cytochrome P450 3A4 & CYP3A4 & 1 & $\begin{array}{l}\text { homo } \\
\text { sapiens }\end{array}$ \\
\hline P09211 & Glutathione S-transferase P & GSTP1 & 2 & $\begin{array}{l}\text { homo } \\
\text { sapiens }\end{array}$ \\
\hline Q99835 & Smoothened homolog & SMO & 1 & $\begin{array}{l}\text { homo } \\
\text { sapiens }\end{array}$ \\
\hline Q9NYA1 & Sphingosine kinase 1 & SPHK1 & 1 & $\begin{array}{l}\text { homo } \\
\text { sapiens }\end{array}$ \\
\hline P48039 & Melatonin receptor type $1 \mathrm{~A}$ & MTNR1A & 1 & $\begin{array}{l}\text { homo } \\
\text { sapiens }\end{array}$ \\
\hline Q03181 & Peroxisome proliferator-activated receptor delta & PPARD & 1 & $\begin{array}{l}\text { homo } \\
\text { sapiens }\end{array}$ \\
\hline P10145 & Interleukin-8 & CXCL8 & 1 & $\begin{array}{l}\text { homo } \\
\text { sapiens }\end{array}$ \\
\hline P62993 & Growth factor receptor-bound protein 2 & GRB2 & 1 & $\begin{array}{l}\text { homo } \\
\text { sapiens }\end{array}$ \\
\hline P01857 & Immunoglobulin heavy constant gamma 1 & IGHG1 & 2 & $\begin{array}{l}\text { homo } \\
\text { sapiens }\end{array}$ \\
\hline P35228 & Nitric oxide synthase & NOS2 & 20 & $\begin{array}{l}\text { homo } \\
\text { sapiens }\end{array}$ \\
\hline
\end{tabular}




\begin{tabular}{|lllll|}
\hline $\begin{array}{l}\text { UniProt- } \\
\text { ID }\end{array}$ & Protein names & $\begin{array}{l}\text { Gene } \\
\text { names }\end{array}$ & Degree & Species \\
\hline P04798 & Cytochrome P450 1A1 & CYP1A1 & 4 & $\begin{array}{l}\text { homo } \\
\text { sapiens }\end{array}$ \\
\hline Q12791 & $\begin{array}{l}\text { Calcium-activated potassium channel subunit alpha- } \\
1\end{array}$ & KCNMA1 & 1 & $\begin{array}{l}\text { homo } \\
\text { sapiens }\end{array}$ \\
\hline $\begin{array}{l}\text { 2, Licorice induced tumor cells cycle arrest mainly by down- } \\
\text { regulating Cyclin D1-CDK4 }\end{array}$ & & & \\
\hline
\end{tabular}

To further study the anti-cancer effect of licorice on NSCLC, we first tested the effects of licorice on the growth of tumor cells. According to the CCK8 assay results shown in Fig. 3a, we could recognize that licorice induced a concentration-dependent inhibition of H1975 cell proliferation. Treating licorice two days with concentrations of 3200,5600 and $7200 \mu \mathrm{g} / \mathrm{mL}$, we found that compared with DMSO treatment, the $\mathrm{H} 1975$ cell growth decreased by 25,48 and $87 \%$, respectively. Moreover, the IC50 value on it were $5400 \mu \mathrm{g} / \mathrm{mL}$.

Next, given the analysis of systems pharmacology for licorice, and a number of studies have shown that the negative effects of licorice or its relatives on cell cycle progression $[15,16,19,20]$, we reasoned that licorice might influenced cell cycle to exert the anti-tumor effect on NSCLC to some extent. To test the hypothesis, we treated $\mathrm{H} 1975$ cells with different concentrations of licorice followed by flow cytometry analysis of cell cycle profile. Strikingly, $\mathrm{H} 1975$ cells subjected to licorice led to a significant increase in the number of cells arrested at G0/G1 growth phase, in a dose-dependent manner, compared with vehicle control containing media (shown in Fig. 3b and Fig. 3c). At the same time, the number of cells at both $\mathrm{S}$ growth phase and G2/M growth phase slightly decreased (Fig. 3c). This finding consistent with previous study that licorice induced G1 cell cycle arrest in MCF-7 human breast cancer cells[16].

It has been known that cyclin-dependent kinase (CDK)/cyclin complexes, such as CDK2/Cyclin E, CDK4, CDK6/CyclinD1, and P21 play crucial roles in cell cycle progression[21]. Therefore, to elucidate the underlying molecular mechanism with which licorice induced cell cycle arrest at G0/G1 growth phase, immunoblot analysis were performed to evaluate cell cycle-related protein abundance in vitro experiment. Notably, we found that the levels of CDK4, cyclin D1 were reduced, and the effect was concentration dependent, while the expression of CyclinB1 and CyclinA2 was relatively maintained at the level of the control group following licorice treatment (Fig. 3d and Fig. 3e). Interestingly, the expression of p21, a CDK inhibitor, was slightly decreased in response to licorice exposure vs control group (shown in Fig. 2d).

In addition, previous work uncovered that cyclin D1 degradation occurs mainly at the G1/S phase boundary [21, 22]. Collectively, these results indicated that licorice is likely to induce tumor cells arrested at G0/G1 growth phase by down-regulating CDK4-Cyclin D1 complex.

\section{3, Licorice positively regulates PD-L1 protein abundance}


It has been shown that PD-L1 expression can be modulated at both transcriptional and post-translational levels, however, it is not yet clear whether PD-L1 expression is regulated under physiological conditions for example during cell cycle progression[23-26]. In this setting, to further understand the connection between PD-L1 and cell cycle, we used cell synchronization by nocodazole arrest and immunoblot analysis to explore variation of PD-L1 during cell cycle. As shown in Fig. 4a and Fig. 4b, we found that PD-L1 protein expression increased in M/early G1 phases, followed by a great decrease in late G1/S phases.

As our results showed that licorice down-regulated Cyclin D1-CDK4 expression to arrest cell cycle progression, we probed whether licorice participated in variation of PD-L1. To do this, we treated H1975 cells with different concentration of licorice, followed by immunoblotting analysis. Strikingly, licorice administration results in a significant increase in the expression of PD-L1 protein (Fig. 4c and Fig. 4d), in a dose-dependent manner. Furthermore, recent finding had shown that Cyclin D-CDK4 kinase destabilized PD-L1, inhibition of CDK4/6 in vivo increased PD-L1 protein levels[27]. Together, these findings indicating that increased levels of PD-L1 expression by licorice correlated with down-regulation of Cyclin D1-CDK4 expression.

\section{4囚Licorice induce tumor regression by affecting Cyclin D1- CDK4-PD-L1 axis}

Based on previous studies that various natural compounds in licorice possess effective antitumor activity $[14,16,28,29]$, we wanted to know whether licorice can function in vivo to suppress tumor progression for NSCLC. To do so, we utilized C57/BL6 female mice bearing LLC tumor to assess the antitumor impact of licorice. And size-matched tumor-bearing mice (TBMs) were divided into 4 groups randomly and received the administrations (as depicted in Fig. 5a).

By day 20 of treatment, as expected, all control mice encountered humane endpoints. Then mouse from each group were killed and dissected tumor, mouse serum was taken out and stored for subsequent experiment.

It is critical to note that licorice treatment result in a $64.9 \%$ tumor volume regression, and we found that there was slightly inhibitory effect on tumor volume of mice treated with anti-PD-L1 antibody alone vs control mice. Interestingly, we also observed a 54.7\% tumor volume reduction in licorice + anti-PD-L1 mice compared with control mice over time. (Fig. 5a).

In keeping with our finding of tumor volume, treatment of licorice led to a significant induction of tumor weight, this also occurred in licorice + anti-PD-L1 group compared with untreated group. However, slight reduction of tumor weight was observed in anti-PD-L1 alone group (Fig. 5b).

Having pinpointed the critical role for licorice in affecting Cyclin D1-CDK4 expression in vitro, we next examined whether licorice had similar influence in vivo. Therefore, we assayed cell cycle-related protein for tumor tissue using the immunoblot method. Consistent with earlier observations in vitro (Fig. 3d), 
licorice treatment markedly reduced the abundance of CDK4 Cyclin D1, and importantly led to a dramatic PD-L1 accumulation compared with control group (Fig. 5c and 5d).

Therefore, these results coherently indicated that licorice might mainly function through down-regulating CDK4-Cyclin D1 to stabilize PD-L1 and subsequently suppress tumor progression.

\section{5, Licorice increased antigen presentation and infiltration of $\mathrm{CD}^{+} \mathrm{T}$ cell}

Furthermore, the results of systems pharmacology analysis indicated that kinds of compounds of licorice correlated with $\mathrm{CD} 8^{+} \mathrm{T}$-cell (Fig. 6a, figure S2a, figure S2b), then intratumoral $\mathrm{CD} 8^{+} \mathrm{T}$-cell infiltration in tumor tissue lysates were measured by flow cytometry analysis. Importantly, CD8 ${ }^{+} \mathrm{T}$ cell infiltration of licorice-treated mice we detected increased by $6 \%$ of that in untreated mice (Fig. $6 \mathrm{c}$, Fig. $6 \mathrm{~d}$ and figure S2c). In further support of a physiological role for licorice in promoting $C D 8^{+} T$ cell infiltration, we used the mice serum to perform ELISA-based assays and found a remarkable increase of IFN-yin licorice-treated mice (Fig. 6e). These results were in line with a previous study that CDK4/6 inhibitors induce breast cancer cell cytostasis and enhance their capacity to present antigen and stimulate cytotoxic $T$ cells[30].

Next, to gain insights into the physiological role of licorice in modulating tumor regression at gene level, RT-qPCR analysis was performed. Specifically, we sought to determine relative mRNA levels of antigen presentation genes by RT-qPCR analysis, and observed that transporter-MHC interactions (Tap-bp) had at least a $15 x$ fold increase in licorice-treated tumor tissues compared to control tumor samples, and peptide transporters (Tap1 and Tap2) were also markedly up-regulated in licorice-treated tumors, although directing peptide cleavage (Erap1) hardly change to some extent. (Fig. 6b).

Altogether, these studies indicated that licorice increased expression of antigen presentation genes and promoted $\mathrm{CD} 8^{+} \mathrm{T}$ cell infiltration for tumor tissue.

\section{Discussion}

Natural products were shown broadly to interfere growth signals by multi-specific actions[31], which may open an opportunity to treat NSCLC effectively. In a panel of human cancers, licorice has been uncovered to provide growth-limiting activities[16, 28,32]. Although changes in the cell-cycle have been noted under licorice treatment settings[19,20], dissecting mechanism of the biological activity of licorice remains a challenge. Here, the critical findings of our study, summarized in Fig. $5 \mathrm{c}$ and Fig. $2 \mathrm{~d}$, include the discovery that licorice limits lung cancer growth mainly related with down-regulating CDK4-Cyclin D1 complex and enhancing intra-tumoral $\mathrm{CD} 8^{+} \mathrm{T}$ cell infiltration. Our detailed investigation shows that licorice induce $\mathrm{G} 1$ cell-cycle arrest in lung cancer cells by inhibiting CDK4-Cyclin D1 complex, which in turn increase PD-L1 levels and antigen presentation and results in intra-tumoral $C D 8^{+} T$ cell infiltration. These findings convincingly argue for a potential treatment option of licorice in the prevention and treatment of NSCLC. 
Beginning with systems pharmacology analysis, flow cytometry analysis of cell cycle profile and immunoblotting, we observed that licorice treatment led to G1 cell-cycle arrest and inhibit the expression of CDK4-Cyclin D1 complex in $\mathrm{H} 1975$ cells. This biological activity was further validated in licorice-treated tumor. It is well known that CDK4-Cyclin D1 complex were required for progression of cells cycle through the G0/G1 phase[33-35], which would suggest that $\mathrm{G} 1$ cell-cycle arrest is largely associated with decreased levels of CDK4-Cyclin D1 after licorice treatment. One of the strongest links between CDK4Cyclin D1 complex down-regulation and tumor regression has come from inhibitor studies. As a kind of CDK4/6 inhibitors, abemaciclib caused regression of bulky tumors in mouse models of mammary carcinoma[30]. Furthermore, many human cancers harbor genomic or transcriptional aberrations that could activate CDK4/6[36-38]. Therefore, our finding that licorice inhibit the expression of CDK4-Cyclin D1 complex would be critically important for prevention and treatment of cancers.

Moreover, Cyclin D/CDK4 was found negatively regulates PD-L1 protein stability in several tumor cell lines[27, 39]. And previous studies revealed that response to PD-1/PD-L1 blockade might correlate with PD-L1 expression levels in tumor cells[40-42]. Notably, we discovered that licorice treatment induced increased expression of PD-L1 levels both in vitro and in vivo. These studies, together with our findings, shed light on a viable option for the management of NSCLC, with or without other treatments in conjunction, to enhance the efficiency of cancer immunotherapies.

The functional impairment of T cell-mediated immunity in the TME is a defining feature sharing by many cancers, and $C D 8^{+} T$ cells became the central focus of new cancer therapeutics $[43,44]$. Due to the data that shows licorice increased expression of antigen presentation genes and promoted $\mathrm{CD} 8^{+} \mathrm{T}$ cell infiltration for tumor tissue, we reasoned that $\mathrm{CD}^{+} \mathrm{T}$ cell infiltration contribute to growth inhibition for tumor.

In summary, this study evidenced that licorice induced G0/G1 phase cell cycle arrest by down-regulating CDK4-Cyclin D1 complex on tumor cells, in addition, licorice increased expression of antigen presentation genes and infiltration of CD8 $+T$ cell in tumor microenvironment. Therefore, this study illuminated a novel mechanism of anti-tumor effect of licorice in NSCLC treatment, and provide functional evidence for development of natural products in anti-tumor immunity.

\section{Methods}

\section{Pharmacokinetic evaluation}

the ingredients of licorice were identified based on searching literatures and using Traditional Chinese Medicine Systems Pharmacology Database (TCMSP, http://tcmspw.com/)[45] and active ingredients (shown in Table 1) were further screened out by in silico ADME system, with the criteria of oral bioavailability $(\mathrm{OB}) \geq 50 \%$ and drug-likeness $(\mathrm{DL}) \geq 0.40$.

\section{Target fishing and validation}


We identified direct targets of licorice on the basis of a WES method and a SysDT tool, then obtained targets were uploaded to Uniprot (http://www.uniprot.org)[46] to normalize their name and organisms. And the targets of Homo sapiens were chosen for further investigation. We used Cytoscape 3.7.0 software to construct and analyze compound-target network.

GO enrichment analysis and KEGG analysis for targets.

(GO) enrichment analysis and KEGG analysis was performed through mapping targets to DAVID (http://david.abcc.ncifcrf.gov) for classification. We chose the terms with P value less than 0.05 .

\section{Cell proliferation assay}

Cellular proliferation was assayed using a Cell Counting Kit-8 (CCK-8, Beyotime, China). In brief, $1 \times 10^{4}$ cells were seeded in 96-well microplates. After $24 \mathrm{~h}$, cells were treated with different concentrations of licorice or vehicle for $48 \mathrm{~h}$. Then, $10 \mu \mathrm{L} \mathrm{CCK}-8$ solution was added to each well and incubated at $37^{\circ} \mathrm{C}$ for $4 \mathrm{~h}$. Absorbance at $450 \mathrm{~nm}$ was measured using a microplate reader (Molecular Devices, California, USA)

\section{Cell lines, compounds, and reagents}

H1975 LLC (Shanghai, China) were maintained in RPMI medium (C11875500BT,Gibco, Thermo Fisher Scientific) or DMEM (C11995500BT, Gibco, Thermo Fisher Scientific) supplemented with $10 \%$ fetal bovine serum (10099141, Gibco, Thermo Fisher Scientific).

Licorice powder was purchased from LEMETIAN MEDICINE. And Typical HPLC chromatogram of licorice extract performed by LEMETIAN MEDICINE (figure S1).

\section{FACS analysis of cell cycle}

Once $\mathrm{H} 1975$ cells achieved a $70-80 \%$ confluency, they were treated with $0.1 \%$ DMSO or different concentration of licorice for $48 \mathrm{~h}$. Then, cells were fixed with ice-cold $70 \%$ ethanol at $-20^{\circ} \mathrm{C}$ overnight. After fixation, cells were washed thrice with cold PBS and then stained with Cell Cycle and Apoptosis Analysis Kit (C1052, Beyotime Biotechnology) according to the manufacturer's instructions. Samples were then analyzed using a NovoCyte Flow Cytometer (ACEA Biosciences). The results were analyzed by Flow Jo software (BD bioscience.

\section{Western blotting}

For western blot analysis, cells or tumor tissue were lysed in lysis buffer from the Qproteome Mammalian Protein Prep Kit (37901, QIAGEN) with the addition of protease inhibitors after PBS washing. Protein concentrations were measured by a microplate reader (Molecular Devices, California, USA) using the BCA Protein Assay Kit (Beyotime, China). Then equal amounts of protein were resolved on SDS-PAGE and transferred to nitrocellulose membranes ((Millipore, Bedford, MA, USA)) and incubated with primary antibodies against: mouse monoclonal CDK4, cyclin D1 (BD Bioscience, USA); cyclin A2, cyclin B1, P21, PD-L1, B-actin, GAPDH (Santa Cruz Biotechnology, USA) and $\beta$-actin (abcam); Secondary antibodies were goat anti-rabbit HRP. Immunoreactive polypeptides were detected by electrochemiluminescence $(E C L)$ 
reagents (Cat\#170-5061, Bio Rad) using ChemiDoc ${ }^{\text {TM }}$ XRS + Imaging System (Bio-Rad). Western blot band intensity quantification was calculated using ImageJ.

\section{Cell synchronization and FACS analyses}

For synchronization into the $\mathrm{G} 2 / \mathrm{M}$ phase of the cell cycle progression, $\mathrm{H} 1975$ cells were treated with 100 $\mathrm{ng} / \mathrm{mL}$ of nocodazole (M1404, Sigma-Aldrich) for 16 hours. Then cells release was collected at the indicated time points and fixed by $70 \%$ ethanol at $-20^{\circ} \mathrm{C}$ overnight. After fixation, cells were washed 3 times with cold PBS and stained with Cell Cycle and Apoptosis Analysis Kit (C1052, Beyotime Biotechnology) according to the manufacturer's instructions. Stained cells were sorted with NovoCyte Flow Cytometer (ACEA Biosciences). The results were analyzed by Flow Jo software (BD bioscience).

\section{Experimental Model in vivo and Subject Details}

All animal protocols described in this study were approved by the Institutional Animal Care and Use Committee (IACUC: 2018120202) at The Kanion Parmaceutical. C57BL/ 6 female mice (purchased from The Comparative medicine center of Yangzhou University) with 6-8 weeks of age were used. To generate tumor model, $5^{\star} 10^{5}$ LLC cells were injected into the flanks of mice. Two days after inoculation, mice were randomized into four groups and treated with licorice, licorice + PD-L1, PD-L1 or vehicle for 2 weeks. Licorice was administered daily by gastric gavage ( $200 \mathrm{mg} / \mathrm{kg}$ of body weight); Anti-PD-L1 (B7-H1) (10F.9G2) (BE0101, BioXCell) was administered by intraperitoneal (i.p.) injection on day 4, 7, and 10 after inoculation. ( $200 \mathrm{mg} / \mathrm{kg}$ of body weight); control mice were treated with vehicle $(0.9 \% \mathrm{NaCL}) 5 \mathrm{ml} / \mathrm{kg}$ by intraperitoneal (i.p.) injection. Tumor size was measured as indicated in the figures, and tumor volume was calculated by using the formula: $1 / 2 \times$ length $\times$ width ${ }^{2}$. Mice with tumors greater than $1,500 \mathrm{~mm}^{3}$ were sacrificed and tumors were collected and snap-frozen.

\section{Real-Time RT-PCR analyses}

Total RNAs were extracted using the RNeasy mini kit (74106, QIAGEN), and reverse transcription reactions were performed using the Prime Script RT reagent Kit with gDNA Eraser (Perfect Real Time) (RR047A, Takara). After mixing the generated cDNA templates with primers/probes and Green ${ }^{\circledR}$ Premix Ex Taq ${ }^{T M}$ II (Tli RNaseH Plus) (RR820B $(A \times 2)$, Takara), reactions were performed with the Step One Plus TM RealTime PCR System (Applied Biosystems).

Mouse GAPDH: Forward, 5'-AGGTCGGTGTGAACGGATTTG-3',

Reverse, 5'-GGGGTCGTTGATGGCAACA-3';

Mouse Tap1: Forward, GGACTTGCCTTGTTCCGAGAG,

Reverse, GCTGCCACATAACTGATAGCGA;

Mouse Tap-2: Forward, CTGGCGGACATGGCTTTACTT,

Reverse, CTCCCACTTTTAGCAGTCCCC; 
Mouse Tap-bp: Forward, GGCCTGTCTAAGAAACCTGCC

Reverse, CCACCTTGAAGTATAGCTTTGGG

Mouse Erap1: Forward, TAATGGAGACTCATTCCCTTGGA

Reverse, AAAGTCAGAGTGCTGAGGTTTG

\section{Single cell generation from tumor tissue and flow cytometry analysis}

Tumor tissues were minced and digested with Collagenase IV (2mg/ml, 17104-019, Gibco) and DNase I (2000U/ml, D7073, Beyotime) and Hyaluronidase $(0.5 \mathrm{mg} / \mathrm{ml}, \mathrm{S} 10060$, YuanYe Biotechnology) and Dispase $\mathbb{\nabla}\left(0.5 \mathrm{mg} / \mathrm{ml}, \mathrm{S} 25046\right.$, YuanYe Biotechnology) in DMEM for $30 \mathrm{~min}$ at $37^{\circ} \mathrm{C}$. Cells were then collected by centrifuge and filtered through a $70 \mu \mathrm{m}$ strainer (15-1070 BIOLOGIX) in DMEM. Cell pellets were suspended and lysed in red blood cell lysis buffer (Beyotime Biotechnology) for $5 \mathrm{~min}$. The cells were then filtered through a $40 \mu \mathrm{m}$ strainer (15-1040, BIOLOGIX) in $1 \times$ PBS with $2 \%$ BSA. $1 * 10^{6}$ cells were incubated with antibodies against Anti-mouse CD3e APC (145-2C11) (05122-80-25, Biogems), Anti-mouse CD8a PE (53 - 6.7) (100707, BioLegend), Anti-mouse CD45 PE/Cy7 (30-F11) (103114, BioLegend) at room temperature for $30 \mathrm{~min}$. Cells were washed by $1 \times$ PBS with $2 \%$ BSA 3 times and detected by NovoCyte Flow Cytometer (ACEA Biosciences).

\section{Elisa analysis}

Cytokines of mouse serum in licorice-treated group and control group were analyzed according to the manufacturer's recommendations: Mouse IFN-y Immunoassay (USA R\&D Systems, Inc.). Absorbance was measured on a microplate reader (Molecular Devices, California, USA) using Prism 8.0.2 (GraphPad Software, Inc.).

\section{QUANTIFICATION AND STATISTICAL ANALYSIS}

Statistical analyses were performed with Prism 8.0.2 (GraphPad Software, Inc.). Two groups comparison using student's $t$ test. Multiple comparisons using one-way analysis of variance (ANOVA) followed by Tukey test. Tumor volume were analyzed using two-way ANOVA followed by Tukey test. Differences were considered statistically significant at a $p$ value $\leq 0.05$. Data are presented as the mean $\pm S E M . * p<0.05$,

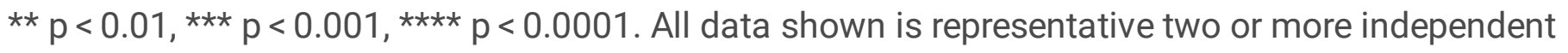
experiments, unless indicated otherwise.

\section{Declarations}

\section{Declarations}

Ethics approval and consent to participate 
All animal protocols described in this study were approved by the Institutional Animal Care and Use Committee (IACUC: 2018120202) at The Kanion Parmaceutical.

\section{Consent for publication}

We would like to declare on behalf of my co-authors that the work described was original research that has not been published previously, and not under consideration for publication elsewhere, in whole or in part. No conflict of interest exits in the submission of this manuscript, and manuscript is approved by all authors for publication.

\section{Availability of data and materials}

All other data are included within the Article or Supplementary Information or available from the authors on request.

\section{Competing interests}

The authors declare no competing interests.

\section{Funding}

This work was supported by the National Natural Science Foundation of China (Grant No. 81803960), the 64th batch of postdoctoral general programs in China (Grant No. 2018M643723), and National Science and Technology Major Project of China (Grant No. 2019ZX09201004-001).

\section{Authors' contributions}

Ruifei Huang and Jinglin Zhu contributing equally to this work. Ruifei Huang, Jinglin Zhu, Ruijie Yang, and Yue Xiao, Jiangna Yan carried out the experiment. Ruifei Huang wrote the manuscript with support from Chunli Zheng and Chao Huang. Wei Xiao and Yonghua Wang helped supervise the project. Chunli Zheng and Chao Huang conceived the original idea.

\section{Acknowledgements}

We thank Jiangsu Kanion Pharmaceutical, Co., Itd. for helpful experimental support.

\section{References}

1. Ferlay, J., et al., Estimating the global cancer incidence and mortality in 2018: GLOBOCAN sources and methods. Int J Cancer, 2019. 144(8): p. 1941-1953.

2. Kao, S., et al., IGDB.NSCLC: integrated genomic database of non-small cell lung cancer. Nucleic Acids Res, 2012. 40(Database issue): p. D972-7.

3. Al-Yozbaki, M., et al., Targeting DNA methyltransferases in Non-small-cell lung cancer. Semin Cancer Biol, 2021.

4. Pilipow, K., A. Darwich, and A. Losurdo, T-cell-based breast cancer immunotherapy. Semin Cancer Biol, 2020. 
5. Zheng, $\mathrm{H}$., et al., HDAC Inhibitors Enhance T-Cell Chemokine Expression and Augment Response to PD-1 Immunotherapy in Lung Adenocarcinoma. Clin Cancer Res, 2016. 22(16): p. 4119-32.

6. Edwards, J., et al., CD103(+) Tumor-Resident CD8(+) T Cells Are Associated with Improved Survival in Immunotherapy-Naive Melanoma Patients and Expand Significantly During Anti-PD-1 Treatment. Clin Cancer Res, 2018. 24(13): p. 3036-3045.

7. Chabanon, R.M., et al., PARP inhibition enhances tumor cell-intrinsic immunity in ERCC1-deficient non-small cell lung cancer. J Clin Invest, 2019. 129(3): p. 1211-1228.

8. Zhou, Z. and Z.-R. Lu, Molecular imaging of the tumor microenvironment. Advanced Drug Delivery Reviews, 2017. 113: p. 24-48.

9. Tang, H., J. Qiao, and Y.-X. Fu, Immunotherapy and tumor microenvironment. Cancer Letters, 2016. 370(1): p. 85-90.

10. Becht, E., A. de Reyniès, and W.H. Fridman, Integrating tumor microenvironment with cancer molecular classifications. Genome Medicine, 2015. 7(1).

11. Xu, J., et al., Synergistic Effect and Molecular Mechanisms of Traditional Chinese Medicine on Regulating Tumor Microenvironment and Cancer Cells. Biomed Res Int, 2016. 2016: p. 1490738.

12. He, J., P. Yin, and K. Xu, Effect and Molecular Mechanisms of Traditional Chinese Medicine on Tumor Targeting Tumor-Associated Macrophages. Drug Des Devel Ther, 2020. 14: p. 907-919.

13. Niu, Y., J. Xu, and T. Sun, Cyclin-Dependent Kinases 4/6 Inhibitors in Breast Cancer: Current Status, Resistance, and Combination Strategies. J Cancer, 2019. 10(22): p. 5504-5517.

14. Kanazawa, M., et al., Isoliquiritigenin Inhibits the Growth of Prostate Cancer. European Urology, 2003. 43(5): p. 580-586.

15. Hsu, Y.L., P.L. Kuo, and C.C. Lin, Isoliquiritigenin induces apoptosis and cell cycle arrest through p53dependent pathway in Hep G2 cells. Life Sci, 2005. 77(3): p. 279-92.

16. Jo, E.H., et al., Chemopreventive properties of the ethanol extract of chinese licorice (Glycyrrhiza uralensis) root: induction of apoptosis and $\mathrm{G} 1$ cell cycle arrest in MCF-7 human breast cancer cells. Cancer Lett, 2005. 230(2): p. 239-47.

17. Zheng, C., et al., Large-scale Direct Targeting for Drug Repositioning and Discovery. Sci Rep, 2015. 5: p. 11970.

18. Yu, H., et al., A systematic prediction of multiple drug-target interactions from chemical, genomic, and pharmacological data. PLoS One, 2012. 7(5): p. e37608.

19. Zhou, Y. and W.S. Ho, Combination of liquiritin, isoliquiritin and isoliquirigenin induce apoptotic cell death through upregulating p53 and p21 in the A549 non-small cell lung cancer cells. Oncol Rep, 2014. 31(1): p. 298-304.

20. Ii, T., et al., Induction of cell cycle arrest and p21(CIP1/WAF1) expression in human lung cancer cells by isoliquiritigenin. Cancer Lett, 2004. 207(1): p. 27-35.

21. Alao, J.P., The regulation of cyclin D1 degradation: roles in cancer development and the potential for therapeutic invention. Mol Cancer, 2007. 6: p. 24. 
22. M Hitomi , D.W.S., Cyclin D1 production in cycling cells depends on ras in a cell-cycle-specific manner. Curr Biol, 1999. 9(19): p. 1075-84.

23. Casey, S.C., et al., MYC regulates the antitumor immune response through CD47 and PD- $L$ 1. Science, 2016. 352(6282): p. 227-31.

24. Dorand, R.D., et al., Cdk5 disruption attenuates tumor PD-L 1 expression and promotes antitumor immunity. Science, 2016. 353(6297): p. 399-403.

25. Li, C.W., et al., Glycosylation and stabilization of programmed death ligand-1 suppresses T-cell activity. Nat Commun, 2016. 7: p. 12632.

26. Lim, S.O., et al., Deubiquitination and Stabilization of PD-L 1 by CSN5. Cancer Cell, 2016. 30(6): p. 925939.

27. Zhang, J., et al., Cyclin D-CDK4 kinase destabilizes PD-L 1 via cullin 3-SPOP to control cancer immune surveillance. Nature, 2018. 553(7686): p. 91-95.

28. Hong, S.H., et al., Anti-Proliferative and Pro-Apoptotic Effects of Licochalcone A through ROSMediated Cell Cycle Arrest and Apoptosis in Human Bladder Cancer Cells. Int J Mol Sci, 2019. 20(15).

29. Ayeka, P.A., et al., The immunomodulatory activities of licorice polysaccharides (Glycyrrhiza uralensis Fisch.) in CT 26 tumor-bearing mice. BMC Complement Altern Med, 2017. 17(1): p. 536.

30. Goel, S., et al., CDK4/6 inhibition triggers anti-tumour immunity. Nature, 2017. 548(7668): p. 471-475.

31. Chen, X., et al., Celastrol induces ROS-mediated apoptosis via directly targeting peroxiredoxin-2 in gastric cancer cells. Theranostics, 2020. 10(22): p. 10290-10308.

32. Wu, X., et al., Glycyrrhizin Suppresses the Growth of Human NSCLC Cell Line HCC827 by Downregulating HMGB1 Level. Biomed Res Int, 2018. 2018: p. 6916797.

33. Y Dong , L.S., K Sugimoto, Y Tai, M Tokuda, Cyclin D1-CDK4 complex, a possible critical factor for cell proliferation and prognosis in laryngeal squamous cell carcinomas. Int J Cancer, 2001. 95(4): p. 20915.

34. Schade, A.E., et al., Cyclin D-CDK4 relieves cooperative repression of proliferation and cell cycle gene expression by DREAM and RB. Oncogene, 2019. 38(25): p. 4962-4976.

35. Topacio, B.R., et al., Cyclin D-Cdk4,6 Drives Cell-Cycle Progression via the Retinoblastoma Protein's CTerminal Helix. Mol Cell, 2019. 74(4): p. 758-770 e4.

36. Hamilton, E. and J.R. Infante, Targeting CDK4/6 in patients with cancer. Cancer Treat Rev, 2016. 45: p. 129-38.

37. K Lingfei , Y.P., L Zhengguo, G Jianhua, Z Yaowu, $A$ study on p16, pRb, cdk4 and cyclinD1 expression in non-small cell lung cancers. Cancer Lett, 1998. 130(1-2): p. 93-101.

38. H-B Sun , X.-L.H., M Zhong, D-J Yu, Linc00703 suppresses non-small cell lung cancer progression by modulating CyclinD1/CDK4 expression. Eur Rev Med Pharmacol 2020. 24(11): p. 6131-6138.

39. Jin, X., et al., Phosphorylated RB Promotes Cancer Immunity by Inhibiting NF-kappaB Activation and PD-L1 Expression. Mol Cell, 2019. 73(1): p. 22-35 e6. 
40. Chen, L., et al., CD38-Mediated Immunosuppression as a Mechanism of Tumor Cell Escape from PD1/PD-L1 Blockade. Cancer Discov, 2018. 8(9): p. 1156-1175.

41. Herbst, R.S., et al., Predictive correlates of response to the anti-PD-L1 antibody MPDL3280A in cancer patients. Nature, 2014. 515(7528): p. 563-7.

42. Iwai, Y., Involvement of PD-L 1 on tumor size in the escape from host immune systerm and tumor immunotherapy by PD-L 1 blocked. Proc Natl Acad Sci U S A 99(19): p. 12293-7.

43. Maimela, N.R., S. Liu, and Y. Zhang, Fates of CD8+ T cells in Tumor Microenvironment. Comput Struct Biotechnol J, 2019. 17: p. 1-13.

44. Lanitis, E., et al., Mechanisms regulating T-cell infiltration and activity in solid tumors. Ann Oncol, 2017. 28(suppl_12): p. xii18-xii32.

45. Ru, J., et al., TCMSP: a database of systems pharmacology for drug discovery from herbal medicines. J Cheminform, 2014. 6: p. 13.

46. UniProt, C., UniProt: a worldwide hub of protein knowledge. Nucleic Acids Res, 2019. 47(D1): p. D506D515.

\section{Figures}

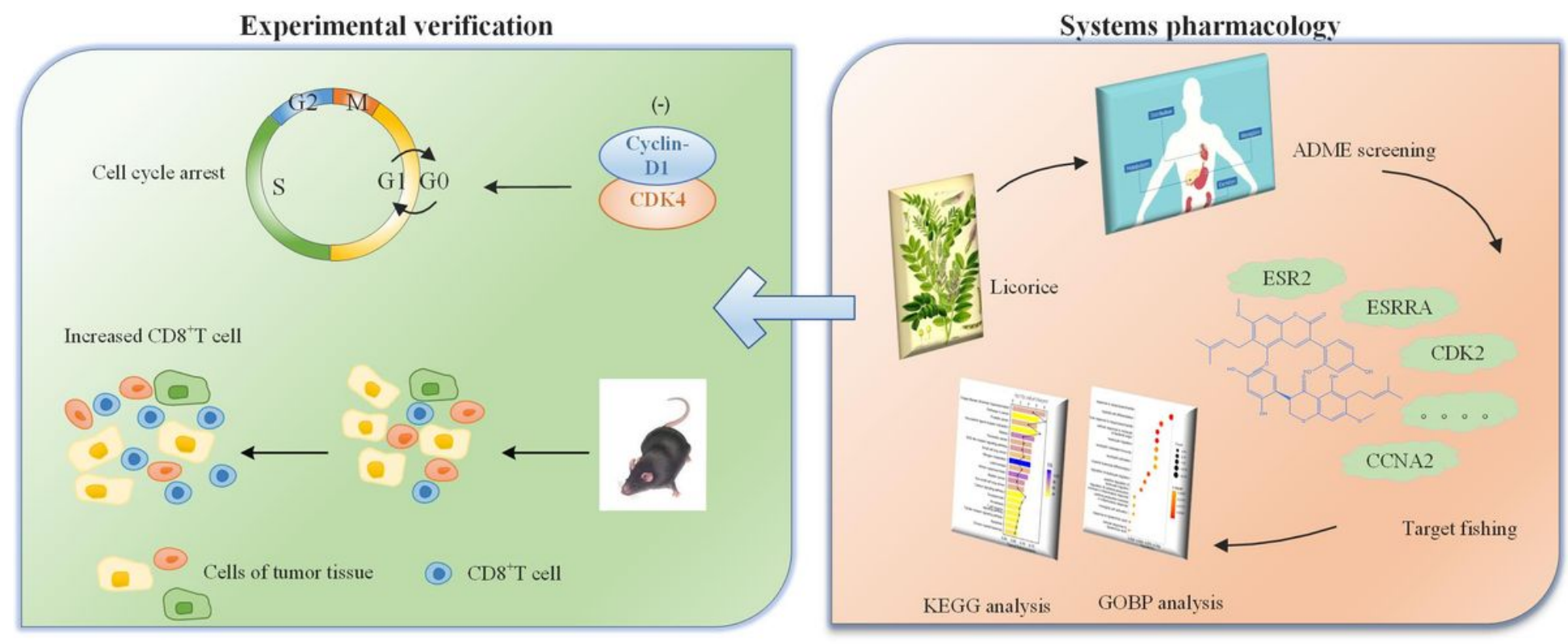

\section{Figure 1}

Workflow of systems pharmacology analysis to undercover mechanism of licorice. 


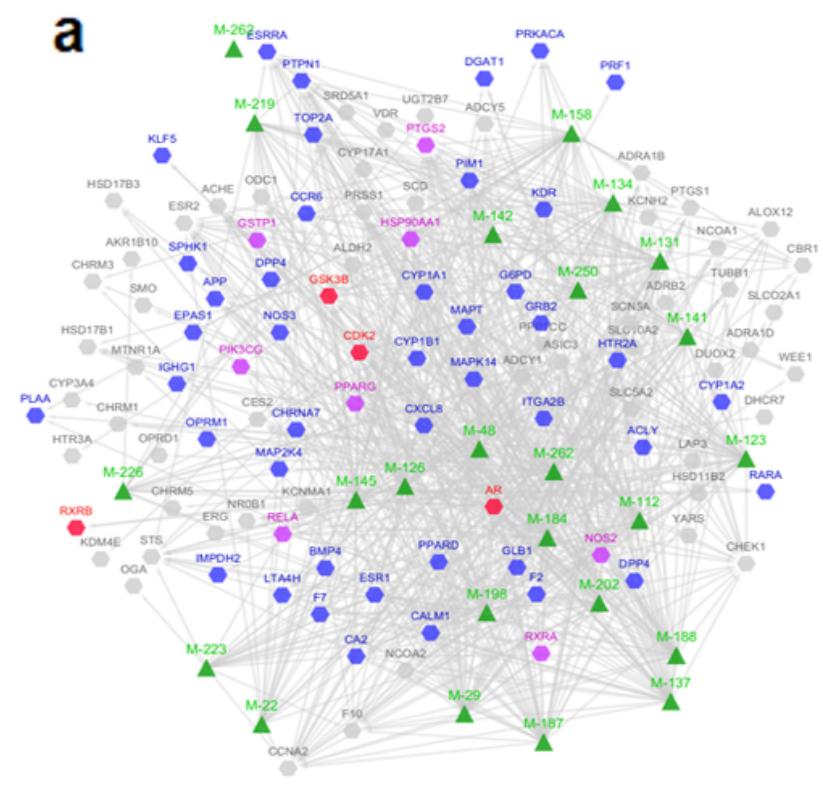

$$
\begin{aligned}
& \text { compounds } \\
& \text { targets related cancer } \\
& \text { targets related immune } \\
& \text { targets related immune and cancer }
\end{aligned}
$$
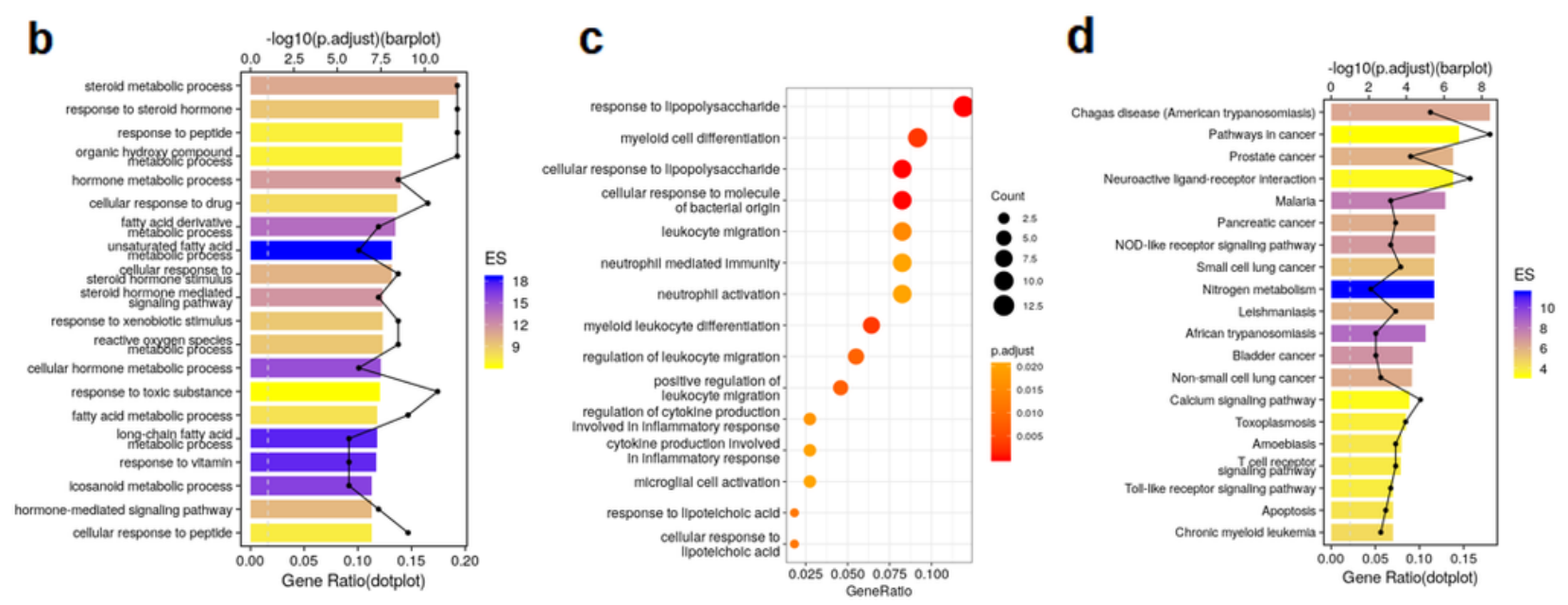

\section{Figure 2}

Systems pharmacology analysis of targets of licorice a Construction of compound-target network, the triangle represents compounds, the octagon represents targets, the edge represents connection between compounds and targets. b GO enrichment analysis of potential targets of licorice, the y-axis represents the enriched GO term, and the GeneRatio represents the number of targets located in this $\mathrm{GO} /$ the total number of targets located in the GO. c GO term associated with immune process were shown, and the size of the circle represents the count. d KEGG analysis of targets of licorice, the color represents the enrichment significance, the $y$-axis represents pathway, and the GeneRatio represents the number of targets located in this KEGG pathway/the total number of targets located in the KEGG pathways. 


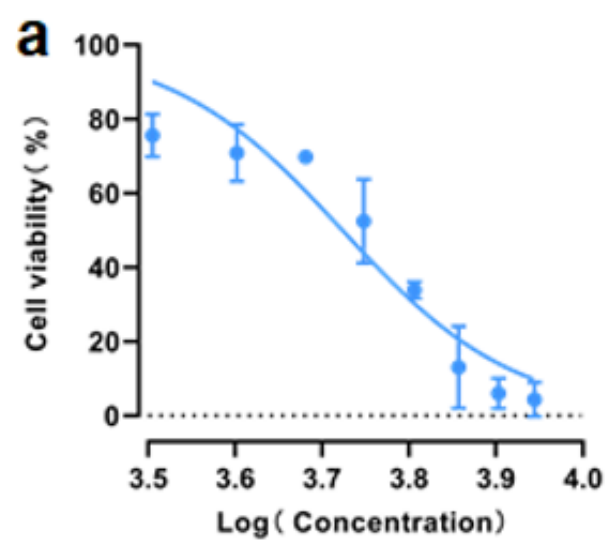

b

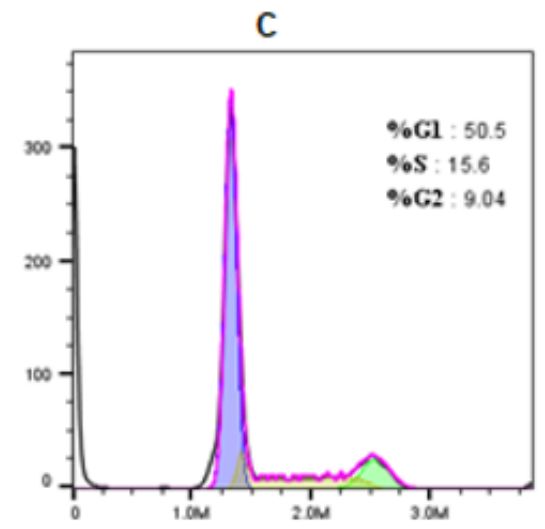

C
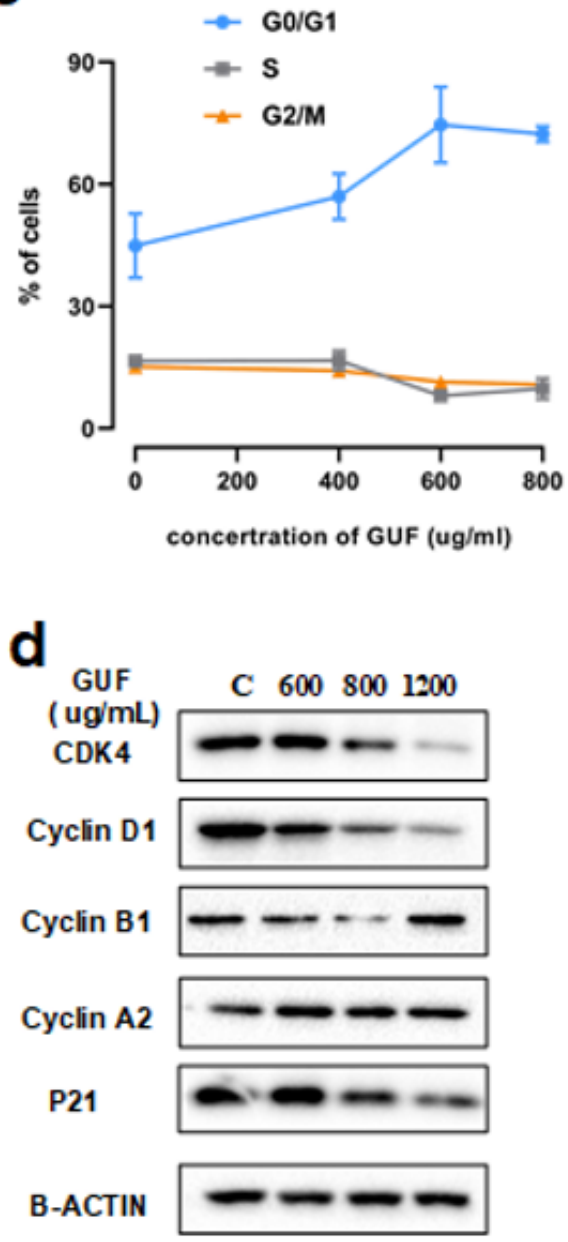

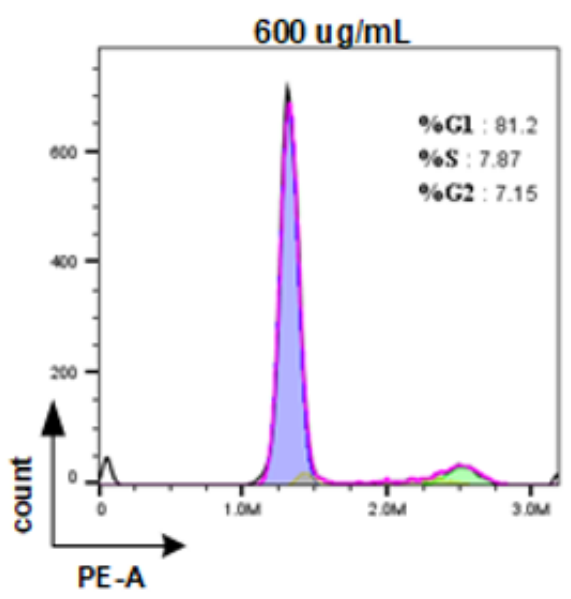

e

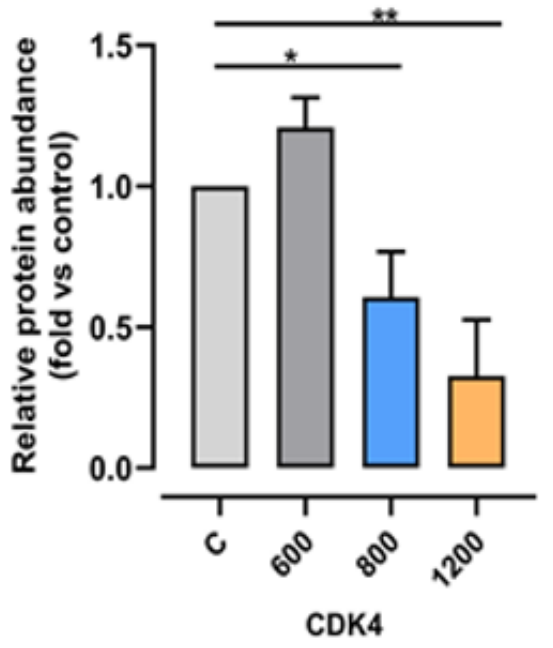

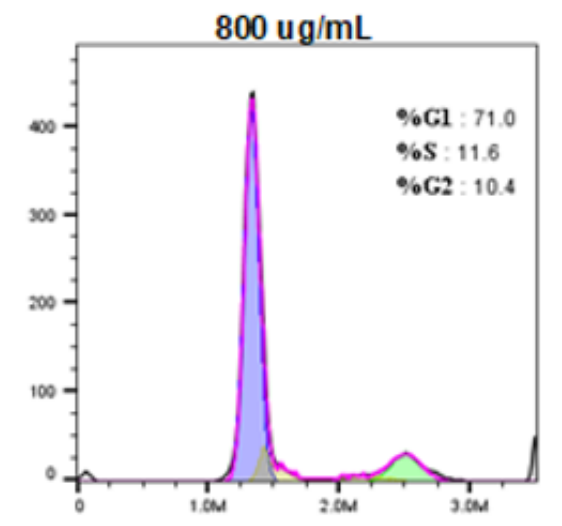
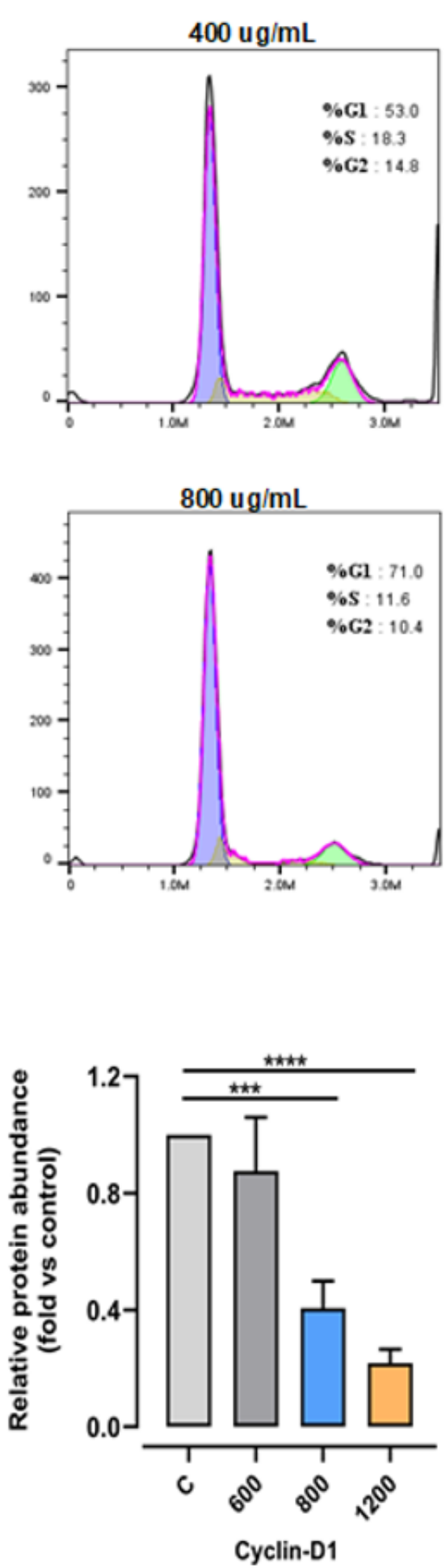

Figure 3

Licorice induce tumor cell G0/G1 phase arrest with the degradation of CDK4-Cyclin D1 complex. a H1975 cells were treated with different concentrations of licorice for $48 \mathrm{~h}$, cell viability was determined using the CCK8 assay. (mean $\pm S E, n=5$ ). b The cell-cycle profiles of $\mathrm{H} 1975$ cells that were incubated with 400ख600区 $800 \mu \mathrm{g} / \mathrm{ml}$ GUF or vehicle control for 48 hours were shown by using fluorescence-activated cell sorting (FACS). c Percentages of H1975 cells in (b) at different cell cycle states. $d$ The protein expression in 
$\mathrm{H} 1975$ cells pretreated with $400 \otimes 600 \rrbracket 800 \mu \mathrm{g} / \mathrm{ml}$ GUF or vehicle control were measured by immunoblots, versus $\beta$-Actin as a loading control. e Relative protein abundance of CDK4 and Cyclin D1 of (d). $\left({ }^{*} p<0.05\right.$, $\star * p<0.01, * * * p<0.001, * * * * p<0.0001)$
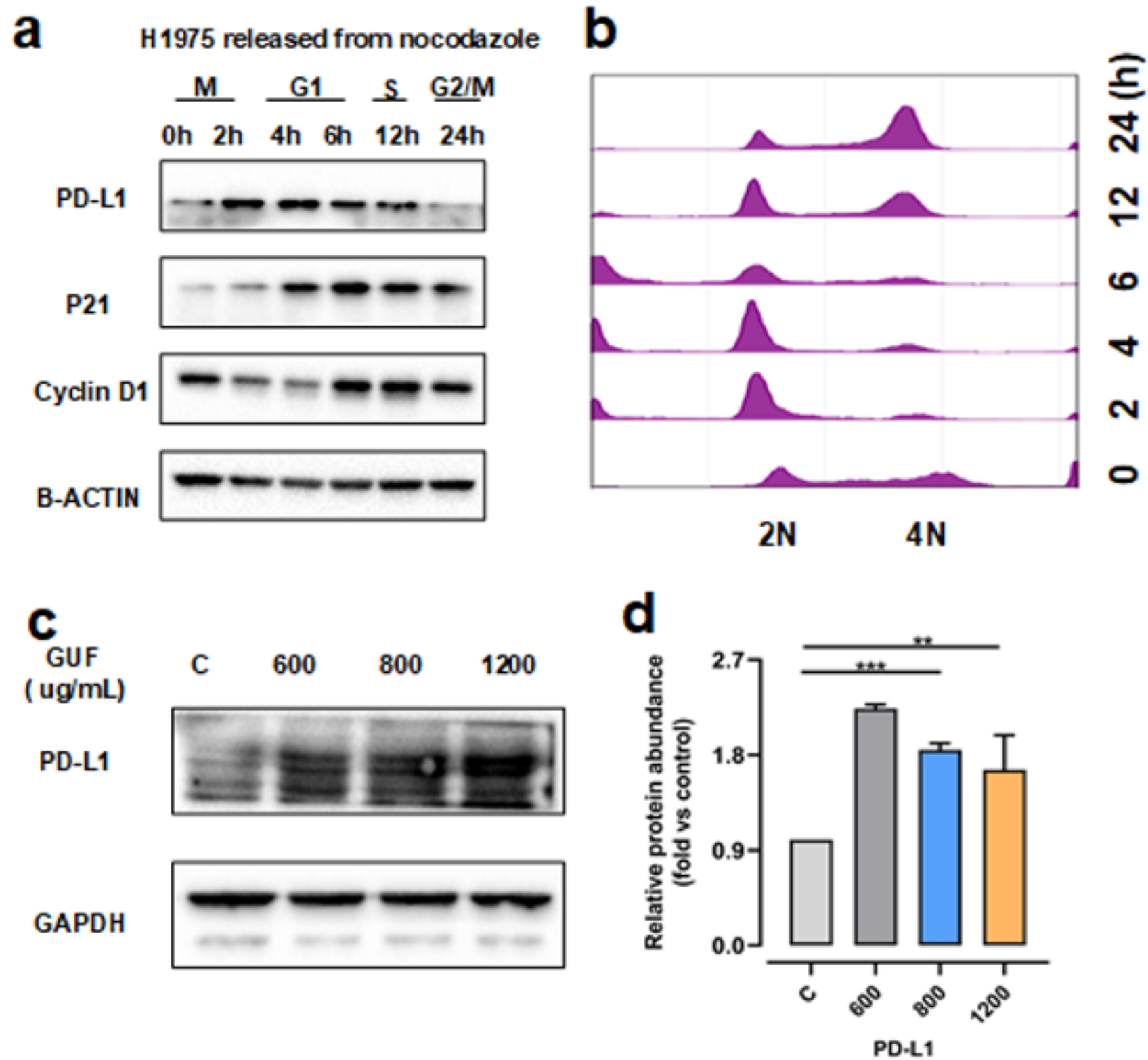

\section{Figure 4}

licorice induced increase of expression level of PD-L1 a Immunoblot (IB) results of whole cell lysates (WCL) derived from $\mathrm{H} 1975$ cells synchronized in M phase by nocodazole treatment prior to releasing back into the cell cycle for the indicated times. b The cell-cycle profiles in (a) were monitored by fluorescence-activated cell sorting (FACS). c The protein expression in H1975 cells pretreated with 400! $600 \rrbracket 800 \mu \mathrm{g} / \mathrm{ml}$ GUF or vehicle control, was measured by immunoblots, versus GAPDH as a loading control d Relative protein abundance of PD-L1 of (c). ( $\left.{ }^{*} p<0.05,{ }^{* *} p<0.01,{ }^{* \star *} p<0.001,{ }^{* * *} p<0.0001\right)$ 

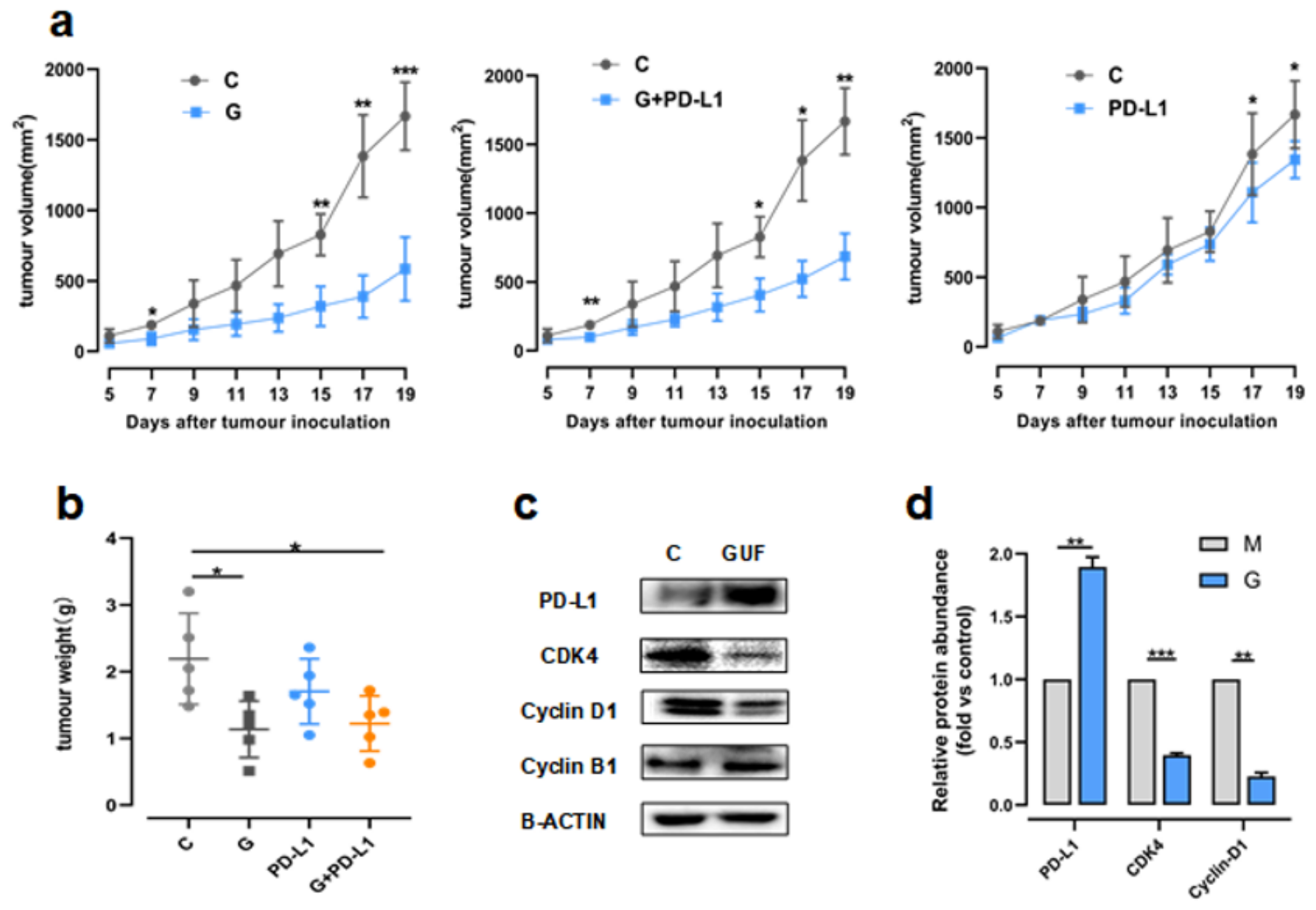

\section{Figure 5}

Licorice inhibit the growth of tumor volume depending on the Cyclin D1-CDK4-PD-L1 axis a C57 BL/6 mice were injected with 5*105 LLC cells. Beginning 24 hours later, $200 \mathrm{mg} / \mathrm{kg}$ GUF or vehicle or anti-PDL1 ( $n=5$ per group) were administered once daily. The tumor growth curve is shown, with tumor sizes presented as mean \pm SEM. $\otimes^{*} P<0.05$. $\mathbb{b}$ Primary tumor mass of mice is shown, presented as mean \pm SEM. c Protein expression in tumors from GUF group and control group was measured by immunoblots, versus $\beta$-Actin as a loading control. $d$ Relative protein abundance of PD-L1, CDK4, Cyclin D1, Cyclin B1 of (c), $\left({ }^{\star} p<0.05,{ }^{\star \star} p<0.01,{ }^{* \star *} p<0.001\right.$.) 
a
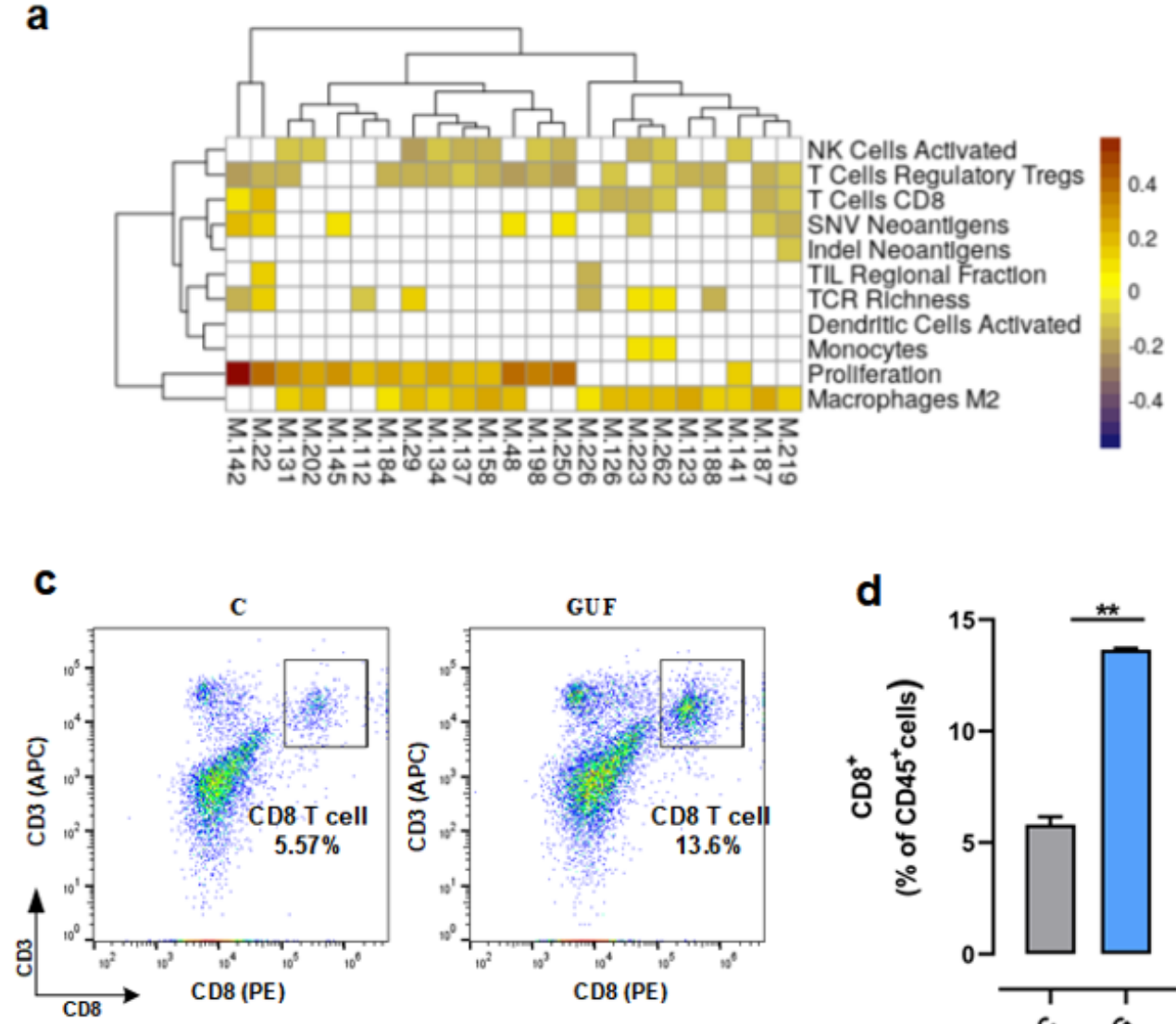

b

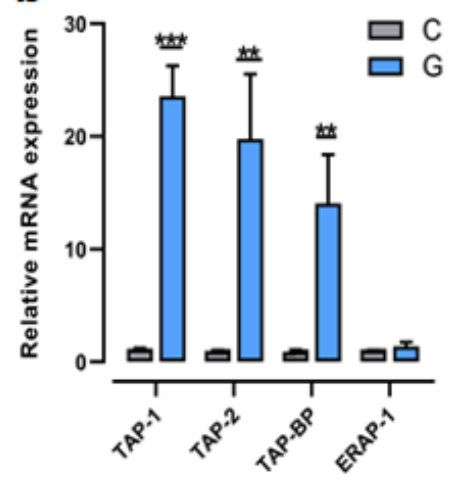

e

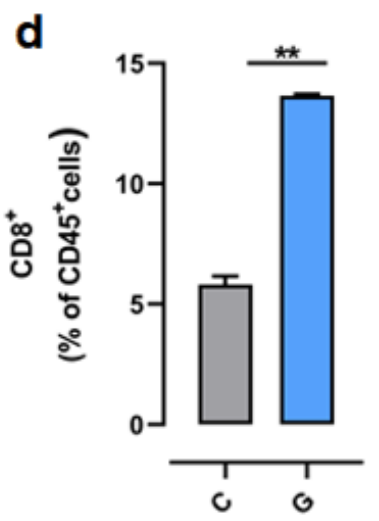

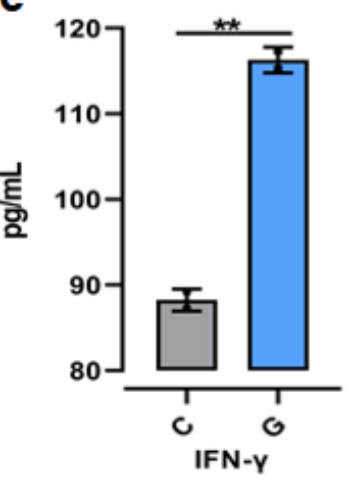

Figure 6

Licorice increased antigen presentation and infiltration of CD8+ T cell in vivo a Heatmap of Pearson's correlation coefficients (PCCs) between gene expression level of targets of licorice and immune phenotypes, the y-axis represents the compounds of licorice. b Relative Quantitative real-time PCR (q RTPCR) analyses of relative mRNA levels of antigen presentation gene from licorice-treated tumors or vehicle. The experiments were repeated three times. Data was analyzed using ANOVA test. c Freshly isolated lymphocytes of tumor tissue samples from the GUF-treated group and control group were stained with anti-CD3, anti-CD45, and anti-CD8 antibodies and infiltration of CD8+ T cells examined by FACS. Representative flow-cytometry plots were shown. $d$ Ratio of infiltration of CD8+ T cells in mice tumor samples from the GUF-treated group versus control group. e Bar graph of IFN-y levels based on ELISA in mice tumor samples from the GUF-treated group and control group were shown. ${ }^{\star \star} p<0.01$, ${ }^{* \star} p$ $<0.001$.)

\section{Supplementary Files}

This is a list of supplementary files associated with this preprint. Click to download.

- Extendeddata.docx 